\title{
TRINITÁRNÍ PERSPEKTIVA TEOLOGIE NÁBOŽENSTVII. NÁSTIN PŘÍSTUPU K NEKŘESŤANSKÝM NÁBOŽENSTVÍM V MYŠLENÍ GAVINA D'COSTY*
}

\author{
M A R T I N K ČÍ
}

$\mathrm{T}$ eologické bádání posledních desetiletí je charakteristické tím, že hledá relevanci trojiční nauky ve všech oblastech teologie. ${ }^{1}$ Objevují se četná pojednání o trinitární eklesiologii, vztahu mezi trinitární a filosofickou teologií, o Trojici a politické teologii, kultuře, teologií manželství a dokonce i vztahu mezi trojiční doktrínou a tzv. „queer theology“ a „gender studies“. V neposlední řadě se dnes řada teologů pokouší na trojičním učení založit přístup k nekřestanským náboženstvím a odhalit nový rozměr dynamického a zároveň ožehavého teologického odvětví, které označujeme jako teologie náboženství. ${ }^{2}$

Právě ona poslední zmíněná oblast, která spojuje křesṫanské učení o Bohu Otci, Synu a Duchu svatém s teologickou reflexí ostatních náboženství, je předmětem této studie. K volbě tohoto tématu máme hned dvojí motivaci: (i) v české teologii se dosud nikdo nevěnoval teologii náboženství z trojiční perspektivy; (ii) vstoupit do těchto „teologických vod“ znamená dialog s anglosaskou teologií, která je

* Věnováno Denise Červenkové, bez které by tato studie nevznikla.

1 Druhá polovina 20. století v tomto směru znamenala renesanci trinitární teologie. Srov. např. RIKHOF, Herwi. The Current Renaissance of the Theology of the Trinity. Bijdragen. International Journal in Philosophy and Theology 2009, roč. 70, s. 423-457. GRENZ, Stanley. Rediscovering the Triune God. The Trinity in Contemporary Theology. Minneapolis: Fortess Press, 2004. WELCH, Claude. In This Name: The Doctrine of the Trinity in Contemporary Theology. New York: Charles Scribner's Sons, 1952.

2 K stručnému přehledu jednotlivých pokusů a motivací trinitární teologie náboženstvi srov. WILLIAMS, Stephen. The Trinity and 'Other Religions'. In VANHOOZER, Kevin J. (ed.). The Trinity in a Pluralistic Age. Theological Essays on Culture and Religion. Grand Rapids: Eerdmans, 1997, s. 26-40. 
v našem prostředí spíše opomíjeným hlasem. Jsou to právě anglicky píšící teologové, kteří v posledních letech věnovali nemalé úsilí, aby prozkoumali možnosti tzv. trinitární teologie náboženství.

Někteří autoři tvrdí, že trinitární teologii není v souvislosti s teologií náboženství věnováno dostatečné množství pozornosti. Například luterský teolog Carl Braaten zastává mínění, že „důležitost trojiční nauky pro křestanskou teologii náboženství zůstává stále nesmírně podceněna.“7 Daniel L. Migliore k tomu dodává, že „jsme stále ještě v počátečním stádiu nového zájmu ohledně rozvinutí trinitární perspektivy pohledu na náboženský pluralismus.“4

Musíme uznat, že tato tvrzení jsou na jedné straně pravdivá, protože se záplavou literatury na téma trojiční orientace teologie náboženství se vskutku nesetkáme. Na straně druhé je nutné zpochybnit absolutní platnost citovaných výroků a poznamenat, že hledání trinitárního modelu, na kterém by bylo možné postavit vztah křestáanství k ostatním náboženstvím, má svou tradici. ${ }^{5}$ Pozornost si jistě zaslouží také to, že tato tradice vykrystalizovala zejména mezi katolickými teology. ${ }^{6}$

Jedním ze současných trendů je tak snaha nalézt takový metodologický přístup, ve kterém by trinitární teologie sloužila jako východisko teologické reflexe mimokřestanských náboženství. Britský katolický teolog Gavin D’Costa přináší do diskuse konkrétní návrh. D’Costovo pojetí je některými teology dokonce považováno za nejrozvinutější a nejpropracovanější nástin tzv. trinitární teologie náboženství. ${ }^{7}$ Označení nástin je důležité podtrhnout. Nicméně i tak se dílo britského autora již dnes těší badatelské pozornosti a je poměr-

3 BRAATEN, Carl E. No Other Gospel. Christianity Among the World's Religions. Minneapolis: Fortress Press, 1992, s. 7.

4 MIGLIORE, Daniel L. Trinity and the Theology of Religions. In VOLF, Miroslav WELKER, Michael (ed.). God's Life in Trinity. Minneapolis: Fortress Press, 2006, s. 103.

5 Svědčí o tom skutečnost, že na toto téma byla publikována přehledová monografie, která se snaží mapovat rozličné pokusy na poli trinitární teologie náboženství. Srov. KÄRK K ̈̈INEN, Veli-Matti. Trinity and Religious Pluralism. The Doctrine of the Trinity in Christian Theology of Religions. Aldershot: Ashgate, 2004.

6 Protestantský teolog Pan-Chiu Lai říká: „Zdá se, že katoličtí teologové věnují více pozornosti důsledkům, které vyplývají z učení o Trojici pro teologii náboženství, než je tomu u teologů protestantských. Z toho plyne, že někteří současní protestanti diskutující trojiční přístup, navazují spíše na díla moderních katolických teologů." PAN-CHIU LAI. Towards a Trinitarian Theology of Religions - a Study of Paul Tillich's Thought. Kampen: Kok Pharos Publishing House, 1994, s. 43.

Srov. KÄRKK ̈̈̈NEN, Veli-Matti. Trinity and Religious Pluralism, s. 76. 
ně hojně diskutováno jako důležitý příspěvek do recentní teologické debaty. ${ }^{8}$

V této studii se postavíme do řady interpretů Gavina D’Costy a pokusíme se jeho myšlení představit a kriticky jej zhodnotit. Postupovat budeme následujícím způsobem. Nejprve představíme jeho tezi o Trojici jako rozlišujícím kritériu křest́anské víry. Následně se budeme věnovat problému dialektického vztahu mezi pojmy universalita a partikularita. V dalším kroku se zaměříme na autorovu pneumatologicko-eklesiální perspektivu teologie náboženství. A na závěr položíme otázku po metodologickém založení teologie náboženství britského autora. Jinými slovy se zaměříme na to, jakou roli zaujímá Trojice, trojiční víra a trinitární teologie v teologickém konceptu Gavina D'Costy.

8 Svědčí o tom i několik disertačních prací, které byly na téma D’Costovy trinitární orientace teologie náboženství zpracovány, ačkoliv se jedná o stále se rozvíjející koncept živého teologa. Srov. BONG, John. Contemporary Catholic Theology of Religions and the Problem of Christology. A Study of Paul Knitter, Gavin D'Costa and Jacques Dupuis. Rome: Gregorianum, 1999; SANTAMARIA DEL RIO, Luis. Trinidad Y Pluralismo Religioso en Gavin D'Costa. Lineas fundamentals de su propuesta teologica. Salamanca: Pontifical University of Salamanca, 2007; PLATA, Przemyslaw. The Trinitarian Theology of Jacques Dupuis, S. Mark Heim and Gavin D'Costa in Contemporary Interreligious Dialogue. Leuven: Katholieke Universiteit Leuven, 2007. Z poslední zmíněné disertace byl publikován výstup pod názvem: Gavin D'Costa's Trinitarian Theology of Religions. Louvain Studies 2005, roč. 30, s. 299-324. Je ovšem nutno podotknout, že po přečtení této studie by se mohlo zdát, že Plata chápe trinitární teologii jako pouhou kombinací christologie a pneumatologie a tak s autorovým hodnocením nelze zcela souhlasit. Z dalších publikovaných studií je třeba zmínit FLETT, John G. In the Name of the Father, the Son and the Holy Spirit. A Critical Reflection on the Trinitarian Theologies of Religion of S. Mark Heim and Gavin D'Costa. International Journal for Systematic Theology 2008, roč. 10, s. 73-90. A následně kapitoly věnované D’Costovi v několika přehledových manuálech k teologii náboženství: srov. KÄRKK ÄINEN, Veli-Matti. Gavin D'Costa. Trinitarian Theology of Religions. In An Introduction to the Theology of Religions. Biblical, Historical and Contemporary Perspectives. Downers Grove: InterVarsity Press, 2003, s. 216-223; TÝŽ. Gavin D’Costa: A Catholic Trinitarian Theology of Religions. In Trinity and Religious Pluralism, s. 67-80. Velmi zajímavý př́íspěvek k bádání ohledně D’Costova návrhu trojičně orientované teologie náboženství představuje rozšířená recenze jeho knihy The Meeting of Religions and the Trinity, pod níž jsou podepsáni pluralističtí teologové. Srov. HICK, John COHN-SHERBOK, Dan - PEACOCK, John. Roundtable Review: The Meeting of Religions and the Trinity. Reviews in Religion \& Theology 2001, roč. 8, s. 232-250. V české teologické literatuře se setkáme se stručným pojednáním o D’Costovi pouze v přehledové monografii Pavla Hoška, který upozorňuje na trinitární rámec teologie náboženství britského teologa. Podrobněji jej však neanalyzuje. Srov. HOŠEK, Pavel. Na cestě $k$ dialogu. Krestáanská víra v pluralitě náboženství. Praha: Návrat Domů, 2005, s. 134-135. 


\section{Trojice jako rozlišující kritérium křest’anské víry}

„Tajemství Nejsvětější Trojice je hlavní tajemství víry a křestanského života. Je to tajemství Boha, jaký je sám o sobě.“9 D’Costa s tímto výrokem samozřejmě souzní. Avšak jeho myšlení v tomto ohledu nenavazuje pouze na magisteriální učení, ale vychází především z Karla Bartha, který nezastřeně zdůrazňoval, že víra v Trojjediného Boha je podstatně rozlišujícím znakem křestanů od vyznavačů jiných náboženství. ${ }^{10}$ Zcela logicky tak vyvstávají otázky: Proč právě trinitární teologie náboženství? Jaký smysl má postavit teologickou reflexi nekřestáanských náboženství na prvku, který křestanství od ostatních tradic tak podstatně odlišuje? Nebylo by přece jen lépe vyjít od obecně sdílených hodnot a naukových konvergencí?

Například katolický teolog David Tracy navrhuje, abychom v teologii náboženství vycházeli od obecně sdílených lidských hodnot (např. soucit, spravedlnost, láska atd.). Konsekventně, mezináboženský dialog by před doktrinálními tématy měl dát přednost dialektice mysticko-prorockého jádra náboženství, které je podle Tracyho vlastní každé tradici. ${ }^{11}$ Hans Küng přichází s podobným návrhem, když chce stavět především na obecně sdílených etických hodnotách a hodlá kombinovat teologický rozměr reflexe náboženství s religionisticko-komparatistickým. ${ }^{12}$ Naproti tomu protestantský teolog Jürgen Moltmann považuje za východisko teologie náboženství universální eschatologický horizont dějin, ke kterému směřuje každé

9 Katechismus katolické církve. Kostelní Vydří: KNA, 2002, č. 234.

10 „Nauka o Trojici je základním prvkem, který odlišuje křestanské učení o Bohu jako křestanské. Je tím, co odlišuje křestanský koncept zjevení jako křestanský v kontrastu ke všem ostatním možným naukám o Bohu nebo konceptům zjevení.“ BARTH, Karl. Church Dogmatics I/1. Edinburgh: T\&T Clark, 1990, s. 301. D’Costa nenavazuje na Bartha nekriticky. Dokonce se vymezuje vůči typu exklusivismu, který rozvinuli někteří Barthovi následovníci. Ve zde zmíněném smyslu ovšem přijímá Barthovo stanovisko kladně. Srov. D’COSTA, Gavin. Christianity and Other Religions. In COHN SHERBOK, Dan (ed.). Many Mansions. Interfaith and Religious Intolerance. London: Bellew Publishing, 1992, s. 33-34.

11 Srov. TR ACY, David. Dialogue with the Other. The Inter-Religious Dialogue. Michigan: W.B. Eerdmans, 1990, s. 7.

12 Srov. KÜNG, Hans. Svétový étos. Projekt. Zlín: Archa, 1992, s. 83-96. Nutno podotknout, že D’Costa se ke Küngovu návrhu universální etiky staví zdrženlivě. Srov. D'COSTA, Gavin. Postmodernity and Religious Pluralism. Is a Common Global Ethic Possible or Desirable? In WARD, Graham (ed.). The Blackwell Companion to Postmodern Theology, Oxford: Blackwell, 2001, s. 131-143. 
náboženství a v podstatě celé lidstvo. ${ }^{13}$ Jiný nestor protestantské teologie, Wolfhart Pannenberg dává namísto vyhraněného teologického přístupu přednost fenomenologickému studiu dějin náboženství a náboženské zkušenosti. ${ }^{14}$

D’Costa volí zcela odlišný směr. Vychází totiž z předpokladu, že není možné vystoupit z vlastní tradice a její specifičnosti. ${ }^{15}$ Podle něj je třeba zůstat uvnitř své tradice a tedy jejího hermeneutického přístupu ke světu. V teologické reflexi je tak nutné začít od partikulárních charakteristik vlastní náboženské identity, respektive vlastní víry. ${ }^{16}$ Zároveň však podtrhuje, že práve specifikum křestanství, což je trojiční orientace, nabízí autentickou otevřenost směrem k ostatním náboženstvím. ${ }^{17}$

Teologie náboženství, která má své východisko v přesvědčení, že není jiného boha, než jediného Boha Otce, Syna a Ducha svatého, vytváří podle britského teologa zdravé dialektické napětí v teologické reflexi nekřestanských náboženství. Toto dialektické napětí podle D'Costy osvobozuje teologickou reflexi nekřestanských náboženství od tendencí tato náboženství a priori odmítat jako nevěrnost Bohu, nebo na druhé straně je a priori potvrzovat jako jiné vyjádření, respektive jiné artikulace téhož, v co věří křestané. ${ }^{18}$ Trinitární orientace teologie náboženství vede společenství církve a jednotlivé křestany spíše k tomu, aby se ostatními náboženskými tradi-

13 Srov. MOLTMANN, Jürgen. Christianity and the World Religions. In HICK, John HEBBLETHWAITE, Brian (ed.). Christianity and Other Religions. Philadelphia: Fortress Press, 1980, s. 191-192.

14 Srov. PANNENBERG, Wolfhart. Die Religionen als Thema der Theologie. Theologische Quartalsschrift 1989, roč. 169, s. 99-110.

15 D'CosTA, Gavin. Whose Objectivity? Which Neutrality? The Doomed Quest for a Neutral Vantage Point from which to Judge Religions. Religious Studies 1993, roč. 29, s. $75-95$.

16 „Identita věřící osoby je formovaná na základě narativní struktury [teologie, liturgie, praxe, atd.], skrze niž je vykládán svět, konkrétní osoba, společenství a Bůh (nebo jakýkoliv jiný konečný smysl). V tomto směru [...] nemůže být náboženská víra osoby vyňata ze své socio-historické skutečnosti.“ D’COSTA, Gavin. Christ, the Trinity, and the Religious Plurality. In D'COSTA, Gavin (ed.). Christian Uniqueness Reconsidered. The Myth of a Pluralistic Theology of Religions. Maryknoll NY: Orbis Books, 1990, s. 18.

17 „Otec je známý skrze Krista a Ducha. Jedině na základě této partikularity jsme schopni Bohu přiznat universální obnovitelské a vykupitelské působení, protože tento Bůh je vždy a všude Bohem Trojjediným, který se zjevil v Kristu.“ D’COSTA, Gavin. Toward a Trinitarian Theology of Religions. In CORNILLE, Catherine NECKEBROUCK, Valeer (ed.). A Universal Faith? Peoples, Cultures, Religions and the Christ. Louvain - Grand Rapids: Peeters Press - W.B. Eerdmans, 1991, s. 147.

18 Srov. D'COSTA, Gavin. Toward a Trinitarian Theology of Religions, s. 147. 
cemi autenticky zabývali, vstoupili s nimi do vzájemného dialogu, naslouchali jim a dokonce byli připraveni se od nich učit. ${ }^{19}$

Nyní vysvětlíme pozici britského autora podrobněji. Na následujících řádcích se zaměříme na rozbor onoho dialektického napětí, o kterém D'Costa mluví jako o dialektice partikularity a universality.

\section{Dialektika partikularity a universality}

D’Costa vyjadřuje obavu, že teologie náboženství se v poslední době „zadrhává“ u problematiky, zda v přístupu k mimokřestanským náboženstvím podtrhnout universalitu Božího spásného působení, či spíše partikulární událost Krista. ${ }^{20} \mathrm{Na}$ jedné straně názorového spektra se nacházejí křest’anští exklusivisté, pro které misijní příkaz: „Jděte ke všem národům a získávejte mi učedníky, křtěte je ve jméno Otce i Syna i Ducha svatého a učte je, aby zachovávali všecko, co jsem vám přikázal“ (Mt 18,19-20), představuje první i poslední slovo o nekřestanských náboženstvích. Křestanství je pro ně jedinou legitimní cestou spásy a všechna ostatní náboženství jsou považována za nevěru. Zastáncům této pozice je potřeba adresovat otázku, zda takto prezentovaný Bůh, neztrácí svou universální tvář, jak ji opisuje Písmo (srov. např. Sk 17,22-28; Řím 1,20; 2,15; 1Tim 2,4) a nestává se spíše kmenovým božstvem západního křestanstva. Na druhé straně jisté směry pluralismu odmítají o Bohu činit jakákoliv definitivní ontologická tvrzení a zastávají názor, že všechna náboženství je třeba vidět jako rozmanité lidské odpovědi na setkání s blíže nespecifikovanou Posledni skutečností. Pluralistů bychom se však měli zeptat, zda v jejich pohledu není přehlížena explicitní partikularita křest’anského Boha (např. Sk 4,12; 1Kor 8,6). ${ }^{21}$ Oba prezentované př́ístu-

19 Srov. D'COSTA, Gavin. The Meeting of Religions. Edinburgh: T\&T Clark, 2000, s. 132-133.

20 V následujícím výkladu se budeme opírat o D’COSTA, Gavin. Toward a Trinitarian Theology of Religions, s. 148-154.

21 Se zde představenou pluralistickou pozicí je spojeno především jméno Johna Hicka, který aplikuje kantovský epistemologický rámec k rozlišení Posledni skutečnosti, která jakožto sama o sobě (Ding an sich) je neuchopitelná a nepoznatelná a jeví se nám pouze parciálně skrze zkušenost setkání s jejím fenomenálním zjevením. Srov. HICK, John. An Interpretation of Religion. Human Responses to the Transcendent. London: Macmillan Press, 1987, s. 241. Christoph Schwöbel se výstižně ptá, zda takový pojem božského noumen, který je podle Hicka nezbytnou myšlenkovou konsekvencí pluralistního náboženského života lidstva, není spíše výsledkem jedné konkrétní „monistické koncepce filosofického teismu, který podtrhuje a vysvětluje fenomenální pluralitu náboženské zkušenosti“. SCHWÖBEL, 
py mají logicky těžkosti s mezináboženským dialogem. První vidí dialog v první řadě jako výzvu k misii s cílem proselytismu. Druzí dialog implicitně negují, protože reinterpretují nebo relativizují náboženskou tradici a identitu „těch druhých“ a neberou své partnery zcela vážně. Jinými slovy, exkluzivisté zdůrazňují roli partikularity na úkor universality, zatímco pluralisté rozpouštějí partikulární odlišnosti $\mathrm{v}$ abstraktním universalismu.

D’Costa se domnívá, že trojičního orientace teologie náboženství dokáže projít mezi Skyllou a Charybdou. V trojiční perspektivě není možné, aby základní otázka teologie náboženství zněla: bud' christocentrismus anebo teocentrismus. ${ }^{22}$ Britský teolog chce zachovat napětí mezi teocentrismem a christocentrismem, respektive mezi universalitou Božího spásného působení a partikularitou události Krista.

\subsection{Partikularita události Krista a vztah křest'anství \\ k ostatním náboženstvím}

D’Costa se ztotožňuje se slovy čtvrtého evangelia, která vyznívají značně exklusivisticky: „Já jsem ta cesta, pravda i život. Nikdo nepřichází k Otci než skrze mne,“ (Jan 14,6). ${ }^{23}$ V partikulární události Krista je přítomná jednoznačná diskontinuita mezi křestanstvím a ostatními náboženstvími. Zdá se tak, že D’Costa má jasné vědomí o Ježíši Kristu ve smyslu, jak se o něm vyjadřuje dokument Mezinárodní teologické komise Křest'anství a ostatní náboženství: „že pouze v jeho osobě je nám nabídnuto sebedarování trinitárního Boha.“24 Przemyslaw Plata shrnuje christologické stanovisko britského autora následujícím způsobem: „Kristus je principem radikální diskontinuity mezi křestanstvím a ostatními náboženstvími. Skutečnost vtělení je základem zásadní jinakosti křestanství.“25 Je tak oprávněné tvrdit, že u D'Costy nacházíme příkřejší zdůraznění ambivalence mezi vírou a náboženstvím, než tomu bývá v katolické teologii po II. vatikánském koncilu obvyklé. ${ }^{26}$

Christoph. Particularity, Universality, and the Religions. In D’COSTA, Gavin (ed.). Christian Uniqueness Reconsidered, s. 32.

22 Srov. D'COSTA, Gavin. Christ, the Trinity, and Religious Plurality, s. 18-19.

23 Srov. D'COSTA, Gavin. The Meeting of Religions, s. 104.

24 MTK. Křestanství a ostatni náboženství. Praha: Krystal OP, 1999, čl. 88.

25 PLATA, Przemyslaw. Gavin D'Costa's Trinitarian Theology of Religions, 301.

26 Byl to Karl Barth, kdo tematizoval ambivalenci mezi vírou, která je odpovědí na zjevení a náboženstvím, jenž je pouhým lidským konstruktem. Srov. BARTH, 
Avšak britský teolog si je dobře vědom také toho, že od nejranějších dob úsvitu křestanství známe teologickou tradici, která počítá s Božím působením mimo viditelné hranice křesṫanského náboženství a církve. ${ }^{27}$ Nauka apologety Justina Mučedníka o tzv. logos spermatikos zdůrazňuje kontinuitu mezi partikulárním zjevením Krista v konkrétním čase a místě dějin a všeobecným zjevením pravdy, které se mohlo (a stále může) odehrát kdykoliv a kdekoliv. Pravda a dobro, které nacházejí příčinu jedině v Kristu lze tedy nalézt i mimo křestanství. Tato pravda je vždy navázána na Krista a na jeho osobu, jak ostatně učí i II. vatikánský koncil: „přece jsou [náboženství] nezřídka odrazem Pravdy, která osvěcuje všechny lidi.“28 Pravda, o které se zde hovoří, je sám Kristus, a tak žádné ze semen slova nemůže představovat fundamentální protiklad tomu, co nacházíme v jeho osobě a jeho životním příběhu. Dostáváme se tak do paradoxní situace. Kristus navzdory, nebo snad díky své partikularitě, představuje „bod“ ustavující mezi křestanstvím a ostatními náboženstvími nikoliv pouze diskontinuitu, ale rovněž kontinuitu. K tomuto závěru míří D’Costa, když nejen připouští, ale přímo podtrhuje nutnost otevřenosti křestanské teologie nacházet pravdu i mimo své vlastní hranice. ${ }^{29}$

Studium nekřestáanských náboženství, jejich jinakosti a diametrální odlišnosti, může přispívat hlubšímu porozumění tajemství Krista. Je důležité zabývat se náboženskými systémy, jejich posvátnými texty

Karl. Church Dogmatics I/2. Edinburgh: T\&T Clark, 1956, s. 314. Barth tímto svým postojem ovlivnil řadu teologů a jeho teze je dodnes diskutována právě mezi těmi, kteří se věnují problematice vztahu křestanství k ostatním náboženstvím. D’Costa jakoby zde byl blíže spíš pohledu protestantského teologa, než všeobecně přijímanému pokoncilnímu stanovisku mezi katolickými teology, které u nás vyjadřuje např. POSPÍŠIL, Ctirad V. Různé přístupy křestanů k ostatním náboženstvím. In HOŠEK, Pavel (ed.). Sbornik evangelikálnich teologů: Křestané a jiná náboženství. Praha: Návrat domů, 2004, s. 99-120.

27 Srov. D'COSTA, Gavin. The Absolute and Relative Nature of the Gospel. Christianity and Other Religions. In BRYANT, M. D. (ed.). Pluralism, Tolerance and Dialogue: Six Studies. Waterloo: Waterloo University Press, 1989, s. 145.

28 NAe 2. (Veškeré citace dokumentů II. vatikánského koncilu jsou vzaty z edice: Dokumenty II. vatikánského koncilu. Kostelní Vydří: Karmelitánské nakladatelství, 2002).

29 Srov. D'COSTA, Gavin. Against Religious Pluralism. In WALKER, Andrew (ed.). Different Gospels: Christian Orthodoxy and Modern Theologies. London: SPCK, 1993, s. 145. Podobně se k témuž vyjadřuje Pospíšil: „V posledních desetiletích se Justinovo učení o Logos spermatikos stává velmi aktuálním vzhledem k otázkám inkulturace i kvůli problematice dialogu s ostatními náboženstvími, ve kterých lze tato semena Slova nacházet a vidět v nich určitou přípravu na evangelium." POSPÍŠIL, Ctirad V. Ježišz zazareta, Pán a Spasitel. Praha - Kostelní Vydří: Krystal OP - Karmelitánské nakladatelství, 2006, s. 120. 
a naukami, spiritualitou, etickou praxí i náboženskou zkušeností. Nelze se spokojit s pozicí vnějšího pozorovatele, je třeba vstupovat do konfrontace $s$ autentickým sebeporozuměním nekřestanských náboženství. ${ }^{30}$ Otázka po působení a přítomnosti Boha mimo křestanství nepovstává z podobnosti, ale právě z jinakosti té které náboženské tradice samotné. Vracíme se tak zpět k diskontinuitě mezi Kristem a náboženstvími.

Diskontinuita mezi náboženstvími a křestanstvím spočívá v tom, že kromě dobra a pravdy lze v náboženstvích nalézt kontaminaci hříchem. ${ }^{31}$ Přestože si je této skutečnosti D'Costa vědom, jeho myšlení postuluje diskontinuitu, která je jiného charakteru. Ta vychází z respektu k ostatním náboženstvím a odmítnutí jakékoliv formy redukcionismu. ${ }^{32}$

Každé náboženství představuje autonomní systém a partikulární tradici. Stejně tak křest́anství je partikulární a autonomní tradicí mezi ostatními. Diskontinuita a neanalogičnost události Krista je normativní pro partikulární křestanskou identitu. Nárok na uznání této kristovské partikularity v sobě obsahuje požadavek uznání a respektu ke každé jiné partikularitě. Zkušenost ostatních náboženství je proto třeba respektovat jako zkušenost diametrálně odlišnou od zkušenosti křestanské. ${ }^{33}$ Taktéž interpretace světa z perspektivy ostatních náboženství je logicky jiná, než interpretace z pozice toho, kdo věří v ukřižovaného a zmrtvýchvstalého Krista. Diskontinuita tak není pouze negativní aspekt vztahu mezi křestanstvím a těmi

30 Sebeporozumènim je míněno to, jak si to které náboženství rozumí samo sobě. Jak interpretuje své posvátné texty, nauku, duchovní zkušenost, rituály, morálku atd. Srov. D'COSTA, Gavin. The Meeting of Religions, s. 116. V tomto směru D'Costa přitakává metodologickému přístupu Raimona Panikkara, jak jej nalezneme v první edici jeho vlivné knihy The Unknown Christ of Hinduism. London: Darton, Longman \& Todd, 1964. Na rozdíl od druhého vydání (1981), které Panikkar přepracoval na základě své filiace k pluralistickému paradigmatu, první verze nabízí podle D'Costy vzor, jak se pravdivě setkávat s jinakostí druhého náboženství. Srov. D'COSTA, Gavin. Christianity and the World Religions: Disputed Questions in the Theology of Religions. Malden MA: Wiley-Blackwell, 2009, s. 41-45.

31 Srov. LG 17, AG 9.

32 Tímto způsobem vyznívá především D'Costova kritika inklusivismu. Srov. D’COSTA, Gavin. The Meeting of Religions, s. 20-24.

33 Podobnou myšlenku vyslovuje italský autor Piero Coda, který podobně jako D’Costa usiluje o založení teologie náboženství na trinitárně teologické perspektivě. K základnímu představení Codových myšlenek srov. TATRANSKÝ, Tomáš. Mezináboženský dialog jako kenotická událost v pojetí Piera Cody. Teologické texty 2007 , roč. 18 , č. 3, s. 134-138. 
druhými. Diskontinuita, kterou reprezentuje osoba Krista, je skutečným základem respektuplného vztahu k ostatním.

\subsection{Universalita Ducha a vztah krest'anství k ostatním náboženstvím}

Přestože se Bůh zjevuje v partikulárním příběhu Ježíše z Nazareta a navzdory tomu, že bez Ježíšova příběhu není z křestanského pohledu možné o Bohu vůbec mluvit, nelze podle D’Costy zjevení Boha připsat osobě Ježíše výlučně. „Bůh se zjevil skrze Ducha $a$ Syna,“ “ŕká D’Costa. ${ }^{34}$ Limitovat cestu poznání Boha výlučně na Ježíšův příběh vede k podřazení nauky o Trojici a upadnutí do christomonismu. Na druhé straně, vidět v jakékoliv reprezentaci božství či transcendence vyjádření vztahu k jednomu a témuž Bohu, nebo jak říkají pluralisté Posledni skutečnosti, je pro trojiční učení stejně deformující a zavání panteismem.

Pneumatologie podle D’Costy představuje teologickou možnost, jak vztáhnout partikulární příběh Krista a jeho poselství k celým dějinám. Z perspektivy čtenáře Bible je Duch svatý osobou, která je ve světě aktivní od stvoření (srov. Gn 1,1-2) a tato aktivita není ničím omezená (srov. Jan 3,8). Logicky proto D’Costa zastává názor, že aktivita třetí osoby Trojice a její možná př́ítomnost není omezená chronologicky ani geograficky.

Je-li vztah křest’anství k ostatním náboženstvím z christologického hlediska především vztahem diskontinuity, tak pneumatologie je podle D’Costy základem pro promýšlení kontinuity. Církev otevřená působení Ducha stojí před výzvou být otevřená také náboženstvím. D'Costa je přesvědčen, že je třeba připustit možnost aktivní př́tomnost třetí osoby Trojice v mimokřestanských náboženstvích. ${ }^{35}$ Pneumatologie tak podpírá snahu o respektuplný přístup k ostatním náboženstvím a otevřenost vůči jejich neredukovatelné jinakosti.

D’Costa přitom důsledně vychází z magisteriálního učení katolické církve. Za klíčové místo považuje Gaudium et spes $22 .{ }^{36}$ D’Costa si velmi dobře všímá, že se zde mluví o Duchu a jeho činnosti mimo

34 D’COSTA, Gavin. Christ, the Trinity, and the Religious Plurality, s. 18 (zvýraznění D'Costa).

35 Srov. D'COSTA, Gavin. The Resurrection, the Holy Spirit and the World Religions. In D'COSTA, Gavin (ed.). Resurrection Reconsidered. Oxford: One World Publications, 1996, s. 158-159.

36 „Zde totiž nacházím explicitní stanovisko, které reflektuje možnou aktivní přítomnost Ducha svatého v nekřestanských náboženstvích [...] i když zůstává nejasné, 
církev ve spojitosti s Kristovým velikonočním tajemstvím. ${ }^{37}$ Osoba Ducha není odtržena od osoby Slova, ani není vyjmuta z vnitrotrinitárního Božského života a vztahů v Trojici. Třetí osoba Trojice tak pro D’Costu nepředstavuje nezávislou ekonomii spásy, Božího zjevení a působení.

Podobný důraz je obsažen i v encyklice Jana Pavla II. Redemptoris missio. ${ }^{38}$ Zde se nejprve zdůrazňuje univerzální působení Ducha, které nezná hranic. Duch je činný v církvi, ale rovněž i mimo ni. Vždy však vede k setkání s Kristem. Orientuje člověka k dobru a pravdě. Avšak nikoliv pouze jedince, ale i celé národy, kultury a náboženství. Mimo křestanství působí jako výzva položená před člověka, jako otázka po smyslu existence a pravdě života. Odpovědi na tyto otázky je podle $R M$ možné nalézt jedině v Kristu. Universální působení Ducha je tak neoddělitelné od partikulární přítomnosti Krista v učednících, kteří tvoří jeho tělo - církev. Církev se proto musí obracet do světa, k rozmanitým kulturám a jiným náboženstvím a odhalovat přítomnost Ducha svatého. ${ }^{39}$ D'Costa navazuje především na poslední zmíněný bod. ${ }^{40}$

V RM stojí: „Každá př́ítomnost Ducha musí být přijímána s pozorností a s vděčností. Avšak rozlišovat ji je úlohou církve, které Kristus dal svého Ducha, aby ji přivedl k plné pravdě.“411 D’Costa vyjadřuje totéž trochu jinými slovy, když říká: „Duch v církvi vede k možnos-

jakého charakteru tato př́tomnost Ducha je.“ D’COSTA, Gavin. The Meeting of Religions, s. 110.

37 „Kristus totiž zemřel za všechny, a protože poslední povolání člověka je ve skutečnosti jen jedno, totiž božské, musíme být přesvědčeni, že Duch svatý všem dává možnost, aby se přičlenili k tomuto velikonočnímu tajemství způsobem, který zná Bůh.“ GS 22.

38 Encyklika byla vydána v roce 1990 (česky: JAN PAVEL II. Redemptoris missio: O stálé platnosti misijního poslání. Praha: Zvon, 1994). [Dále zkracováno jako $R M$ ] V třetí kapitole, konkrétně v části nazvané „Duch je všude a stále přítomný a aktivní“ (čl. 28-29) se nachází základ myšlenek, které Gavin D’Costa rozvíjí. Kapitola „Holy Spirit Invitation“ jeho monografie o Trojici a teologii náboženství je vlastně běžícím komentářem na zmíněné dva články encykliky RM. Srov. D’COSTA, Gavin. The Meeting of Religions, s. 109-117.

39 John Flett dokonce o D’Costovi odvážně tvrdí: „V knize The Meeting of the Religions and the Trinity [D’Costa] nezkoumá Trojici per se, ale spíše se zabývá tvrzením, že Duch svatý může být aktivně přítomný v jiných náboženstvích." FLETT, John. In the Name of the Father, the Son and the Holy Spirit, s. 83.

40 Lze tak souhlasit s Kärkkäinenem, že to nové, co D'Costa přináší v této oblasti je právě souvztažnost pneumatologického rozměru teologie náboženství s eklesiologickou perspektivou. Srov. KÄRKK ÄINEN, Veli-Matti. Trinity and Religious Pluralism, s. 69-70.

41 RM 29. 
ti odhalit kristovskou praxi v jiném. Nakolik se jedná o kristovskou praxi, natolik je umožněna jedině Duchem svatým.“42 Platí totiž, že „[j]edině působením Ducha docházíme my lidé spodobení se vzkříšeným Kristem, novým Adamem, v němž člověk získává nezvratně onu důstojnost, k níž byl povolán již na počátku““.43 Duch obnovuje to, co učinil Kristus. Podle D’Costy je Duch svatý neustálou aktualizací Božího zjevení, které se událo v Kristu. A protože Kristus zjevil Boha jako Trojjediného, tak Duch vždy vede do hlubší a plnější účasti na trinitárním životě. ${ }^{44}$ Protože však Duch svatý nepůsobí jen v srdcích jednotlivců, ale i v celých kulturách a náboženstvích, je Trojjediný př́tomen i v nich. D’Costa, zdá se, jde dál než $R M$ a zastává mínění, že setkání s Duchem v jiných náboženstvích, odhalení jeho přítomnosti v praxích a učeních ostatních náboženských tradic není pro církev „pouhou“ informací, nýbrž může být i obohacením. ${ }^{45}$ Jak tomuto názoru britského teologa rozumět?

$R M$ chce odkrývat Ducha mimo křestáanství, aby nacházela „semena Slova“, která jsou přípravou na plné setkání s Kristem. D’Costa klade před církev výzvu zaobírat se odhalováním Ducha ještě z jiného důvodu. Je totiž přesvědčen, že Duch svatý může církev skrze mimokřestanská náboženství darovat hlubší pochopení vlastní víry a prohloubení věřeného tajemství. ${ }^{46}$

Je ovšem třeba rozlišit mezi hlubšim pochopením a novým zjevením. Britský teolog má spíše na mysli skutečnost první. ${ }^{47}$ Duch svatý

42 D'COSTA, Gavin. The Resurrection, the Holy Spirit and the World Religions, s. 161.

43 MTK. Křestanství a ostatni náboženství 58.

44 Srov. D'COSTA, Gavin. The Meeting of Religions, s. 122.

45 Srov. D'COSTA, Gavin. A Christian Reflection on Some Problems with Discerning God in the World Religions. Dialogue and Alliance 1991, roč. 5, s. 4-17; zde především s. 13-14.

46 K tomuto závěru míří celý D’Costův článek Revelation and Revelations: Discerning God in Other Religions. Beyond a Static Valuation. Modern Theology 1994, roč. 10, s. 165-183; zde především s. 175-181.

47 D’Costa tak implicitně zastává pozici, kterou u nás zdůrazňuje např. Ctirad V. Pospíšil a která se týká vektorické povahy dogmatu, tj. možnosti neustále hlouběji vstupovat do věřeného tajemství křestanské víry při zachování platnosti povahy původního dogmatického vyjádření. Pospíšil upozorňuje, že výrok vzniklý ve specifickém dobovém kontextu nelze zaměňovat s věřeným tajemstvím, které se nedá do slov jakékoliv definice uzavřít s konečnou platností. Dogma, nezměnitelná pravda o Bohu, má povahu ukazatele. „Nereformovatelnost dogmatické definice proto musí být vnímána jako nezrušitelnost a neměnnost udaného směru, zatímco sama zvěstovaná pravda víry může být v budoucnu formulována hlouběji, příhodněji, novým způsobem, zejména vzhledem k nové kulturní a jazykové situaci, v níž se bude Boží lid nacházet." Srov. POSPÍŠIL, Ctirad V. Hermeneutika mystéria. Struktury myšleni v dogmatické teologii. Praha - Kostelní Vydřŕ: Krystal OP - 
může obohatit křestanskou tradici setkáním s jiným. A jedině pokud bude církev otevřená působení Ducha mimo své hranice, bude tomuto Duchu, respektive Trojjedinému Bohu, věrná.

Přítomnost třetí osoby Trojice však nikdy nelze předpokládat apriorně. ${ }^{48}$ Odhalení Ducha svatého mimo křest́anství může podle D’Costy být jedině aposteriorního charakteru. Pouze na základě reálného setkání církve s jiným náboženstvím v něm může být zhodnocena možnost přítomnosti Ducha (v jiném). D’Costa se domnívá, že možné působení Ducha mimo křest’anství je kontinuálním procesem neidentického připomínání Kristova poselství. ${ }^{49}$ Každé odhalení přítomnosti Ducha svatého církví za vlastními hranicemi představuje výzvu inkorporovat tyto nové artikulace Kristova poselství. Závěr britského teologa tak spočívá v tom, že křestané musí ve vztahu k ostatním náboženstvím zaujmout postoj radikální otevřenosti a v tomto postoji setrvat, pokud chtějí být věrni víře v Trojjediného Boha, který je vždy ten jiný. 50

Rozpracování pneumatologického rozměru teologie náboženství a důsledkům z toho plynoucích pro církev se budeme věnovat v následující kapitole.

Karmelitánské nakladatelství, 2005, s. 92-98; zde 94. Za novou situaci křestanství můžeme dnes považovat také neustále intenzivnější mezináboženské setkávání uprostřed pluralitního světa.

D'Costa se v tomto vymezuje proti Barthovi, pro kterého byla všechna náboženství a priori důsledkem lidského sklonu k idolatrii. Srov. NILES, Daniel. Karl Barth A Personal Memory. South East Asian Journal of Theology 1969, roč. 11, s. 10-11. Nesouhlasí ovšem ani s Rahnerem, který předpokládal opačné a priori, že v ostatních náboženstvích jsou prvky milosti. „[J]e $a$ priori pravděpodobné předpokládat, že v nekřestanských náboženstvích jsou nadpřirozené elementy a prvky milosti.“ RAHNER, Karl. Christianity and the non-Christian Religions. In Theological Investigations. Vol. 5, London: Darton, Longman \& Todd, 1966, s. 121. Je všeobecně známo, že tento Rahnerův postoj vedl až tak daleko, že ve vyznavačích ostatních náboženství viděl „anonymní křestany“.

49 Srov. D'COSTA, Gavin. The Meeting of Religions, s. 130.

50 Pokud by byl D'Costa řazen jednoduše mezi inklusivisty (srov. např. HOŠEK, Pavel. Na cestě $k$ dialogu, s. 134), pak jej tento postoj otevřenosti vůči náboženstvím, otevřenosti k novým formulacím Kristova poselství od klasicky pojímaného inklusivismu odlišuje. Křestanství může oprávněně předpokládat, že je zde možnost něco se dozvědět od ostatních náboženství a prohloubit pochopení vlastních tajemství víry. 


\section{Pneumatologicko eklesiální perspektiva trinitární teologie náboženství}

Setkání s třetí osobou Trojice je podle D’Costy vždy setkání s př́ítomným Trojjediným Bohem a také s přítomnou církví. ${ }^{51}$ Světová náboženství tak mají zásadní význam pro společenství církve. Toto tvrzení britskému teologovi vyplývá především z četby Janova evangelia, respektive z interpretace janovských pasáží o paraklétu v rámci Ježíšovi řeči na rozloučenou (Jan 13,31-17,26). D'Costa analyzuje čtyři perikopy $(14,15-18 ; 14,25-27 ; 15,26-27 ; 16,7-15)$ a na jejich základě předkládá závěr, který se týká vnitřní spojitosti mezi Trojicí a církví. ${ }^{2}$ Na následujících řádcích se pokusíme D’Costovu argumentaci shrnout a odpovědět na otázky, které z postoje britského teologa vyplývají.

\subsection{Biblický základ}

Podle čtvrtého evangelia, Syn poslaný Otcem přináší člověku svrchované zjevení o Bohu. Tento Syn posílá a přislibuje svým učedníkům Ducha (srov. 14,15), který je jednak naučí všemu (srov. 14,26) a uvede je do plné pravdy (srov. 16,13) a bude vydávat svědectví o tom, který ho poslal (srov. 15,26). Skrze svědectví Ducha mají být učedníci povzbuzeni, aby také oni vydávali Kristu svědectví (srov. 15,27). Svědectví Ducha a svědectví učedníků je připomenutí (srov. 14,26 a 15,27), respektive interpretací Ježíšova evangelia, které je definitivním zjevením o Bohu.

Janovské uchopení Ježíšova odchodu z tohoto světa, respektive hodiny jeho ukřižování a vzkříšení, je vysvětleno jako přímá inaugurace nové komunity, jako počátek nového stvořeni, které je a bude vedeno dárcem veškerého života - Duchem svatým. ${ }^{53}$ Otázka Ducha v Janově evangeliu je tak podle D’Costy na prvním místě otázkou po učednících, kteří formují církev.

51 Srov. D'COSTA, Gavin. The Meeting of Religions, s. 110.

52 Teologické interpretaci čtvrtého evangelia se D'Costa věnuje v několika studiích. Srov. The Resurrection, the Holy Spirit and the World Religions, s. 150-167; The Meeting of Religions, s. 117-127. Ohledně interpretační metody biblického textu D’Costa sympatizuje s post-kritickým proudem. U nás tento směr prosazuje Jaroslav VOKOUN. Existuje post-kritická biblistika? Studia theologica 2005, roč. 25, s. $46-56$.

53 Srov. D'COSTA, Gavin. The Resurrection, the Holy Spirit and the World Religions, s. 150. 
Jistě se nabízí otázka, jak toto všechno souvisí s teologií náboženství? Ba co víc, jak mohou vybrané pasáže čtvrtého evangelia svědčit o významu ostatních náboženství pro církev? Janovo evangelium se přece látkou ostatních náboženství vůbec nezabývá. Co však Janovo evangelium tematizuje - a D'Costa to podtrhuje - je možná přítomnost Božího Ducha kdekoliv ve stvoření (srov. Jan 3,8). ${ }^{54}$ Na tomto základě argumentují i některé magisteriální dokumenty ve prospěch možného působení třetí osoby Trojice v nekřestanských náboženstvích. ${ }^{55} \mathrm{~A}$ jak zdůrazňuje $R M$, tato možná aktivní přítomnost se netýká pouze srdcí jednotlivců, ale celých náboženských systému a komplexního kulturního rámce, který tato náboženství vytvářejí. 56 Všude tam se lze setkat s přítomným a působícím Duchem svatým.

D'Costa tak četbou Janova evangelia následně ukazuje, že všude, kde se nachází jedna z osob Trojice, je v konečném důsledku př́tomna Trojice celá. A přítomnost Trojice, to má vždy konsekvence pro církev. ${ }^{57}$ Britský teolog chce tedy říct, že pokud církev nezastřeně přiznává možnou přítomnost Ducha svatého v náboženstvích, respektive za hranicemi viditelného křestanství, je základním a důležitým úkolem církve tuto aktivní Boží př́ítomnost v druhých objevovat.

Setkání církve s třetí osobou Trojice v jiném náboženství je přitom podle D’Costy skandální i radostné. ${ }^{58}$ Skandální, protože z jiné náboženské tradice může zaznít nad církví soud ohledně špatné praxe, nebo dokonce ohledně zásadního pochybení na cestě víry. Radostí je však vždy to, že setkání s Duchem přivádí učedníky, tedy církev, blíže ke Kristu a hlouběji do tajemství Trojjediného Boha.

Otazník možného setkání Ducha svatého a kristovské praxe v dialogu s jiným náboženstvím chrání církev před ustrnutím na cestě. Stav církve na zemi, je stavem církve putující. Přílišná jistota, že již byla pravda o Bohu a světě vyčerpána církvi nikdy nesvědčila. Otevřená možnost aktivního působení třetí osoby Trojice za hranicemi křest́anství a následně tak závazek pro církev usilovat o to Ducha

54 Srov. D'COSTA, Gavin. The Meeting of Religions, s. 114.

55 Srov. např. GS 22 a 44; RM 28-29; ale také nemagisteriální dokumenty, nicméně s významnou odbornou autoritou: MTK. Křestanstvi a ostatni náboženství, s. $60-61$.

56 „Přítomnost a působení Ducha se dotýká nejen jednotlivců, ale také společnosti a dějin, národů, kultur a náboženství." RM 28.

57 Srov. D'COSTA, Gavin. The Meeting of Religions, s. 111.

58 Srov. D'COSTA, Gavin. The Meeting of Religions, s. 130. 
v jiných odhalit, je podle D’Costy pro církev důležitou obranou před pokušením nezdravého sebezbožštění. ${ }^{59}$

Sám autor však přiznává, že jeho myšlenkový postup v něm vyvolává řadu otázek: ${ }^{60}$ Není předpoklad o možném setkání Ducha svatého v jiných náboženstvích útokem na jejich vlastní identitu? Neústí tento postoj ke klasické nauce o praeparatio evangelica, tj. že náboženství jsou víceméně anticipací Krista a přípravou na jeho přijetí? Neimplikuje odhalování Ducha svatého v jiných tradicích, že jim jako křestané rozumíme lépe, než snad oni rozumí sami sobě? Především je však třeba spolu s britským teologem položit otázku: „Co to pro církev znamená, když řekneme, že Duch je přítomný mimo její vlastní hranice - v rámci světových náboženství?"61

Odpovědět na otázky a vyjasnit nejasnosti se pokusíme v následujících čtyřech bodech.

\subsection{Náboženská identita}

Podle D'Costy Duch obnovuje učedníky skrze opakovanou, avšak stále novým zpo̊sobem podanou artikulaci Kristova poselství. ${ }^{62}$ Odhalování Ducha, který je činný v ostatních náboženstvích, je jedním z aktuálních úkolů církve, jelikož každé shledání přítomnosti Ducha v jiném je hlubším vstupováním do tajemství Trojice. Odkrytí aktivně působícího Ducha v náboženských tradicích tedy vyžaduje teologickou interpretaci náboženství. Vyslovit domněnku o přítomnosti třetí osoby Trojice $v$ jiném náboženství je tak zřejmě vždy tvrzením intra-křestanským, s kterým vyznavač jiného náboženství rozhodně nebude souhlasit. D'Costa to nazývá slovem hetero-interpretace. ${ }^{63}$

Vyslovit legitimní hetero-interpretaci podle britského autora na prvním místě předpokládá zabývat se velmi vážně a intenzivně náboženskou tradicí, tak jak si sama rozumí, respektive, jak jí rozumí její vyznavači (auto-interpretace). Primární pozornost teologa náboženství tak musí směřovat k tomu, co D’Costa nazývá sebeporozumění. Je

59 Srov. D'COSTA, Gavin. The Resurrection, the Holy Spirit and the World Religions, s. 159.

60 Srov. D'COSTA, Gavin. The Resurrection, the Holy Spirit and the World Religions, s. 164.

61 D'COSTA, Gavin. The Meeting of the Religions, s. 128.

62 Srov D'COSTA, Gavin. The Resurrection, the Holy Spirit and the World Religions, s. 158 .

63 K následujícímu srov. D’COSTA, Gavin. The Meeting of Religions, s. 100n. 
možné a ve skutečnosti také vysoce pravděpodobné, že auto-interpretace bude s hetero-interpretaci ve vzájemném rozporu. Avšak podle britského teologa je pravdou také to, že křestanská hetero-interpretace je vždy odkázána na auto-interpretace druhých. Z tohoto důvodu se D'Costa nedomnívá, že by teologická reflexe nekřestanských náboženství redukovala jejich partikulární identitu. A nejde ani o to, že by snad křestané dokázali tradice druhých číst lépe. Teologie náboženství v D’Costově pojetí chce pouze zůstat věrna svému specifickému narativu, tj. trinitární víře. Odhalení Ducha svatého v jiném náboženství je vždy odvislé od reálného setkání s tímto konkrétním náboženstvím a je nemyslitelné bez hlubokého respektu k identitám všech zúčastněných.

\subsection{Mimokřest'anská náboženství jako znamení príslibu a soudu}

Duch svatý působí, aby církev byla podobnější Kristu. Duch je iniciátorem nového stvoření v srdcích křestanů. Je však také soudcem a odhalitelem každé temnoty, která znemožňuje pravou svobodu Božích dětí. Ostatní náboženství, jejich učení a praxe, mohou promlouvat vủči křestanství právě na znamení soudu. Je-li pravdou, že Duch svatý může posvěcovat ostatní náboženské tradice $\mathrm{v}$ jejich jednání i učení, a dokonce může být přítomný a aktivně působící v celých nekřestanských náboženských systémech, může také tentýž Duch skrze tato náboženství volat křestanství k soudu, pokud se někde zpronevěřilo pravdě. To se může týkat učení i praxe. Křestané jsou skrze jinakost druhých voláni k autentičtějšímu učednictví, k tomu být opravdu novým stvořením. ${ }^{64}$ Kritika, kterou nekřestanská náboženství adresují křestanskému učení, praxi, morálce, liturgii, mohou být mnohdy výzvy k hlubšímu zabývání se vlastní tradicí a výzvy k rozhodným krokům na cestě autentického učednictví.

Zabývání se kritickými námitkami na adresu křestanství ze strany moderní filosofie přivedlo teologickou reflexi k mnoha korekcím

64 Jestliže jsou náboženství autentický locus theologicus, není to pouze požadavek současného kontextu. Jinými slovy vědomí, které vyplývá ze skutečnosti, že křestanství je jedním z mnoha vyznání v nábožensky pluralitním světě. Teologická reflexe nekřestanských náboženství je na prvním místě požadavek teologický. Souhlasně s Gavinem D'Costou se tak vyjadřuje Lieven Boeve: „Z teologicko-epistemologické perspektivy je setkání s jiným vždy situací, ve které může dojít k Božímu narušení. [...] Proto je současný mezináboženský dialog nikoliv pouze kontextuální, nýbrž také teologická nutnost." BOEVE, Lieven. God Interrupts History: Theology in a Time of Upheaval. New York: Continuum, 2007, s. 47. 
křest́anské praxe. Jako příklad lze uvést dnes již klasické dílo moderního myšlení Podstata krestáanství od Ludwiga Feuerbacha, který trefně odhalil úskalí od antropologie odtrženého pojetí Boha a důsledky, ke kterým by takový koncept vedl. ${ }^{65}$ Vedle kritiky vyslovené moderním myšlením je zde ovšem ještě, podle D'Costy často přehlížená, kritika vyslovená vyznavači jiných náboženských systémů. Teologická analýza postojů ostatních náboženství vůči křestanství se podle britského autora stává důležitým loci theologici. Z této perspektivy je tedy možné na ostatní náboženství nahlížet jako na znamení soudu nad křestanstvím, ale na straně druhé, také jako na znamení př́íslibu.

Přítomnost třetí osoby Trojice v ostatních náboženstvích je totiž pro církev radostí. Zaprvé z toho, že zde vedle diskontinuity mezi křestanstvím a ostatními náboženstvími existuje také jakási kontinuita. Tyto dva protikladné prvky jsou tak v neustálém napětí. Zadruhé lze k jinakosti druhých vždy přistupovat s otevřeností a vědomím, že setkání s druhými může církev obohatit o nové formy křestanského učednictví, či obnovit způsoby praxe časem zapomenuté. Biblický základ pro tento směr svého uvažování D'Costa nachází např. v perikopě o milosrdném Samaritánovi (Lk 10,25-37). ${ }^{66}$

\subsection{Kritický přístup k náboženstvím}

Navzdory všemu, co bylo doposud řečeno, je podle D'Costy nutné radikálně odmítnout postoj, který by Duchem svatým chtěl nekriticky zaplavit celý svět, všechna mimokřestanská náboženství a veškeré nekřestanské kultury. Nelze zapomínat, že britský teolog vždy důsledně hovoří o možnosti potkat aktivně působícího Ducha svatého v druhých. V každém případě je nutné odmítnout jakýkoliv apriorní předpoklad, že v každém náboženském projevu, který se bude ke křestanství nebo učení a praxi církve stavě kriticky, je třeba akceptovat jako pravdivý.

65 „Nedělám tedy s náboženstvím - ani se spekulativní filosofií nebo teologií - nic jiného, než že mu otvírám oči, anebo spíše jeho oči obrácené dovnitř, obracím na venek." FEUERBACH, Ludwig. Podstata křestanství. Praha: SNPL, 1954, s. 52. O významu kritiky moderní filosofie a jmenovitě i významu Feuerbacha mluví také POSPÍŠIL, Ctirad V. Jako v nebi, tak i na zemi: Náčrt trinitární teologie. Praha - Kostelní Vydří: Krystal OP - Karmelitánské nakladatelství, 2007, s. 430-439. Pospíšil je tak ukázkou toho, že otevřená teologická reflexe je bezesporu plodnějším zacházením s díly kritiků křestanství, než jednoduchá apologetika, či přímočaré zavrhování autorů a děl, které se vůči křestanství třeba i razantně vymezují.

66 Srov. D'COSTA, Gavin. The Meeting of Religions, s. 130-131. 
Netvrdím, že každá kritika církve je inspirována Duchem svatým. Chci spíše upozornit, že když církev zůstává loajální a otevřená vůči nabádání Ducha, potom musí zůstat otevřena rovněž kritickému tázání nekřestanských náboženství, protože Duch svatý může v těchto náboženstvích aktivně působit. ${ }^{67}$

Radikální otevřenost implikacím plynoucím z mezináboženského setkání, kterou D’Costa zdůrazňuje, musí podle britského autora nacházet svůj základ právě v pevném zakotvení v křestanské tradici a v přesvědčení o legitimitě křestanského nároku na pravdu.

Co se týče křestanství a teologické reflexe ostatních náboženství, tak je D’Costa přesvědčen, že jedině víra v Trojici, respektive trinitární teologie náboženství, zakládá autentickou otevřenost k druhým náboženským tradicím. ${ }^{68}$

\subsection{Dialog a teologie naplnèní}

Podle Gavina D’Costy je zde vnitřní souvislost mezi dialogem s ostatními náboženstvími a misií. Pro misii je podle D’Costy v jistém smyslu charakteristické, že se vždy jedná o setkání s jiným. Setkání s jinakostí, s rozdílnou identitou druhého náboženství, je charakteristická také pro dialog mezi různými náboženstvími. Je to právě dialog, který je nutnou podmínkou toho, aby vůbec k nějakému reálnému setkání s jinakostí druhého došlo. Dialog je vlastně prostorem, ve kterém je možné setkání rozdílných náboženských identit. D'Costa tak říká, že dialog je předběžnou podmínkou misie, a zároveň platí, že v dialogu náboženství nemůže misijní prvek chybět. ${ }^{6}$ Setkání dvou nebo více partikulárních náboženských identit, z nichž každá chce být věrná své specifické tradici, vede podle britského teologa k otevřené možnosti získat druhého na svoji stranu, respektive ke konverzi jako otevřené možnosti mezináboženského dialogu.

67 D'COSTA, Gavin. Revelation and Revelations, s. 178. V téže studii na jiném místě D’Costa říká: „Neměli bychom si plést úctu k jiným náboženstvím s tvrzením, že jejich přesvědčení je pravdivé“ (s. 183).

68 Srov. D'COSTA, Gavin. Trinitarian Différance and the World Religions. In KING, Ursula (ed.). Faith and Praxis in a Postmodern Age. New York: Continuum, 1998, s. $28-46$.

69 „[D]ialogue is actually justified and required by the very nature of mission.“ D'COSTA, Gavin. Revelation and Revelations, s. 176. 
Misie souvisí s teorií naplnění (fulfillment). ${ }^{70} \mathrm{~V}$ dokumentech II. vatikánského koncilu se na několika místech mluví o zaměření mimokřestanských náboženství ke spáse (LG 16), o přítomnosti paprsků pravdy (NAe 2) a semen Slova (AG 11) a o pravdivých a dobrých prvcích, které jsou v náboženství př́tomny (OT 16). Zároveň však platí, že všechny tyto prvky dobra, pravdy a milosti potřebují doplnit, povznést a ozdravit (LG 17; AG 9). Podle dokumentu Křestanství a ostatní náboženství platí, že „ostatní náboženství mohou mít význam jako príprava na evangelium “. ${ }^{71}$ Náboženství tedy mohou obsahovat elementy, které napomáhají lidem k naplnění a dosažení posledního cíle člověka. ${ }^{72}$

D’Costa je s výše uvedeným učením v souladu, dodává však zajímavou a důležitou perspektivu, která v dokumentech učitelského úřadu církve prozatím chybí.

Největším nedostatkem římskokatolických dokumentů o vztahu křestanství k ostatním náboženstvím je jejich jednostranné pojetí teologie naplnění; tj. postoj, že křest́anství je naplněním všeho, co je dobré a svaté v rámci světových náboženství. [...] Avšak v možnosti zaslechnout Boží slovo při setkání s jinými náboženstvími, je sama církev priviádèna k plnosti. ${ }^{73}$

Nejen náboženství nacházejí z křestanského pohledu své naplnění, ale také církev samotná směřuje ke svému naplnění prostřednictvím setkání, dialogu a teologickou reflexí ostatních náboženství. Finální naplnění všeho má pro D’Costu silně eschatologický ráz. ${ }^{74}$ Nejen ostatní náboženství docházejí z křestanského pohledu svého naplnění, ale také církev samotná směřuje ke svému naplnění prostřednictvím setkání, dialogu a teologickou reflexí ostatních náboženství. Tento postoj je podle britského autora odvislý od trojiční orientace teologie náboženství.

70 Srov. D'COSTA, Gavin. The Meeting of Religions, s. 111-117.

71 MTK. Křestanstvi a ostatni náboženstvi, 85.

72 „[P]rotože poslední povolání člověka je ve skutečnosti jen jedno, totiž božské, musíme být přesvědčeni, že Duch svatý všem dává možnost, aby se přičlenili k tomuto velikonočnímu tajemství způsobem, který zná Bůh.“ GS 22.

73 D’COSTA, Gavin. Revelation and Revelations, s. 178 (zvýraznění D’Costa).

74 „Uzdravení, povýšení a zdokonalení jsou charakteristiky nového stvoření. Nové stvoření je však konečně naplněno pouze v eschatologii." D’COSTA, Gavin. The Meeting of Religions, s. 132. 


\section{Trojice jako metodologický princip teologie náboženství}

Zatímco někteří teologové považují trinitární doktrínu za hermeneutický princip náboženské plurality, D’Costa se nedomnívá, že by bylo možno fakt náboženské plurality pomocí trinitární doktríny vysvětlovat, nebo dokonce obhajovat. Ve svém článku „Trinitarian différance and world religions " ${ }^{45}$ ukazuje, že nauka o Trojici by měla být spíše východiskem a přiznaným předporozuměním při následné teologické reflexi ostatních náboženství.

D’Costa se vyjadřuje v tom smyslu, že trinitární doktrína by neměla být používána jako hermeneutický klíč, ale spíše jako teologický nástroj, respektive metodologické východisko, jak uchopit jinakost toho, koho lze z křestanského pohledu označit slovy „ten druhý“, nebo „ten jiný“ (other). Předmětem zájmu D’Costy tak není interpretace náboženské plurality a odhalení jejího tajemství, ale snaha poskytnout metodologický základ pro krestanský přístup k ostatním náboženstvím.

Takový základ lze podle britského teologa spatřovat v trojičním učení křestanské víry. Trojjediný Bůh je vždy ten, který je radikálně jiný. Paradoxně je však zároveň také Bohem, který se zjevil. ${ }^{76}$ Bohem, jenž odhalil svou autentickou tvář v Ježíši Kristu a bez přestání se dává poznávat skrze působení Ducha svatého ve světě. Ve vztahu k Trojjedinému Bohu tak křestané podle D'Costy nacházejí paradoxní napětí mezi totožností (sameness) stále téhož Boha, který se dává svému lidu, a jinakostí (otherness), s jakou se Bůh svému lidu vždy nově dává. ${ }^{77}$ D’Costa o tomto napětí mluví také na základě christologického výroku, že Ježíš je totus Deus, ale nikoliv totum Dei. Na základě tohoto rozlišení D'Costa postuluje prostor pro aktivitu Ducha svatého, který aktualizuje Kristovo poselství o Bohu v každém prostředí a v každé době vždy novým způsobem. ${ }^{78}$

V Kristu a/nebo v křestanské církvi je přítomná Boží pravda. Nicméně tato pravda není nikdy naším vlastnictvím (possession), ale spíše my jsme touto pravdou vlastněni (possessed by). [...] Zatímco tedy církev

75 D'CosTA, Gavin. Trinitarian Différance and the World Religions. In KING, Ursula (ed.). Faith and Praxis in a Postmodern Age, s. 28-46.

76 Srov. D'COSTA, Gavin. Trinitarian Différance, s. 38.

77 Srov. D'COSTA, Gavin. Revelation and Revelations, s. 166-167.

78 Srov. D'COSTA, Gavin. Christ, the Trinity and Religious Plurality, s. 18. 
tvrdí, že se setkala a poznala Boha v sebezjevení Otce v Synu a skrze jejího Ducha (her Spirit), je zároveň přiznáním neznalosti Boha. I když známe Boha, nikdy o Bohu nevíme všechno. ${ }^{79}$

Tento paradoxní vztah je podle D’Costy možné vyjádřit za pomocí termínu différance, který pochází od postmoderního francouzského filosofa Jacquese Derridy. ${ }^{80}$ Différance podle D'Costy vyjadřuje, že o Bohu víme ze zjevení, ale zároveň je k tomu třeba ihned dodat, že o Bohu rozhodně nevíme všechno. D’Costa tak spojuje dvojí. Na straně jedné zvěstování, že Bůh dal lidem dar sebe sama skrze svého Syna Ježíše Krista a vylil Ducha svatého (srov. Tit 3,6). Na straně druhé, že nyní vidíme Boha jen jako $\mathrm{v}$ zrcadle a $\mathrm{v}$ hádance (srov. 1 Kor 13,12). Boha zkrátka nikdo nikdy neviděl (srov. 1 Jan 4,12), dobrou zvěst (evangelium) však zjevil sám Ježíš Kristus (srov. Gal. 1,12).

Skutečná jinakost se může stát otazníkem pro mé vlastní křestanské sebeporozumění; otazníkem, který může být důležitý pro mé vlastní tázání; otazníkem, který obsahuje paprsky zjevení (revelation). ${ }^{81}$

Trinitární teologie v pohledu D'Costy neslouží jako hermeneutický klíč, nýbrž jako základ gramatických pravidel, jak uchopit jinakost ostatních náboženství. Jednou z důležitých implikací D’Costovy argumentace je, že religionistika, případně dějiny náboženství, se mají stát integrálním oborem teologických studií a ne pouze jedním ze studijních programů, které teologické fakulty vypisují. Nekřestanská náboženství hrají totiž v pohledu britského teologa roli významných loci teologického bádání. Trojičně orientovaná teologie náboženství nám tedy neposkytuje specifický hermeneutický klíč k náboženské pluralitě, ale upozorňuje na dodnes málo tematizovanou část hermeneutiky mystéria. Trojiční dogma je východiskem D’Costova systému dle učení Katechismu katolické církve: „toto tajemství je tedy zdrojem všech ostatních tajemství víry; je světlem, které je osvěcuje.

79 D’COSTA, Gavin. Trinitarian Différance, s. 38.

80 Jacques Derrida použil termínu différance poprvé v eseji „Cogito et histoire de la folie“ a vyjadřuje paradoxní napětí mezi stejností (sameness) a radikální jinakosti (radical otherness). Jedná se o enigmatický vztah mezi stejným a jiným. Srov. DERRIDA, Jacques. L'écriture et la différence. Paris: Édition du Seuil, 1967, s. 51-97; (česky: Cogito a dějiny šílenství. In Násili a metafyzika. Praha: Filosofia, 2002, s. 185-234).

81 D'COSTA, Gavin. Trinitarian Différance, s. 39. 
Je to nejzákladnější a nejpodstatnější učení“.82 Na jeho základě pak D'Costa staví stavbu svého systému trinitárně orientované, lépe by však bylo pravděpodobně říkat na trojiční doktríně založené, teologie náboženství. Musíme si však při četbě D’Costova díla být vědomi, že tak činí, aniž by trojiční učení podrobil nějaké kritické reflexi, př́ípadně se opřel o nějakou trinitologickou školu. ${ }^{83}$ Perry Schmidt-Leukel tak trefně poznamenává:

Vzhledem k tomu, že existuje tolik různých variant trojičního učení a mnohé byly prohlášeny za chybné a heretické, bylo by zajímavé, kdybychom se od D'Costy dozvěděli, které z těchto učení je pro něj objektivně pravdivé. ${ }^{84}$

Schmidt-Leukel tak vyslovuje otázku, která dříve nebo později začne trápit každého, kdo se teologií Gavina D’Costy zabývá. U britského teologa nacházíme mnoho slov o Trojici a dủležitosti této nauky. Jsme ujištováni, že trinitární pohled musí být východiskem veškerého křestanského myšlení, ale nikde se nedočteme, jaké konkrétní trinitologické akcenty jsou pro D’Costu podstatné. Nedozvíme se ani k jaké teologické linii má ohledně trojiční doktríny D’Costa blíže. Toto zjištění se zdá být velmi závažné, jelikož D’Costa svůj koncept zve jako trinitární orientace teologie náboženství. Je tedy otázkou, zda Trojice není pro D’Costu pouze hra se slovy, která z něj dělá na první pohled ortodoxního katolického teologa. Shrňme tedy D’Costův nástin.

82 KKC, čl. 234.

83 Jedinou otázku z oblasti trinitologie, kterou D’Costa dílčím způsobem řeší, je vztah mezi imanentní a ekonomickou trojicí. Staví se na stranu těch, kteří nesouhlasí s tvrzením Karla Rahnera: „Ekonomická Trojice je imanentní Trojice a imanentní Trojice je ekonomická Trojice“ (RAHNER, Karl. The Trinity. Kent: Burns \& Oates, 1970, s. 22). D’Costa tvrdí: „Zatímco ekonomická Trojice je imanentní Trojice, tak imanentní Trojice není ekonomická Trojice až do eschatologického věku“ (D’COSTA, Gavin. Trinitarian différance, s. 38-39). Z toho britský teolog vyvozuje, že trojiční učení zakládá možnost vyvarovat se ukvapenému redukcionismu i jednoduchého negativismu. Trojiční nauka nakonec podle D’Costy zakládá opravdový přístup k jinakosti, která se namísto nebezpečí, či nevědomého participování na pravdě křestanství, stává zásadní výzvou pro křestanské sebeporozumění. Srov. D’COSTA, Gavin. Trinitarian Différance, s. 38-40.

84 SCHMIDT-LEUKEL, Perry. Orthodoxy and Religious Pluralism: A Rejoinder. Modern Theology 2008, roč. 24, s. 280. 


\section{Závèr}

Jak jsme se již zmínili v úvodu, vedle důrazného apelu na trojiční doktrínu v oblastech eklesiologie, politiky a sociálního uspořádání společnosti, rodiny, ekologie, atd., je rovněž soudobá teologie náboženství zaměřena na hledání významu nauky o Trojici ve vztahu k mimokřestanským náboženstvím.

Existují návrhy, které považují Trojici, respektive trojiční nauku, za klíč k náboženské pluralitě a řešení problémů a otázek s ní spojených. Zjevný problém některých „trinitárních teologií náboženství“ se však zdá být, že jejich proponenti, ačkoliv se dovolávají Trojice, nevycházejí z vlastní zpracované trinitární teologie. Mezi tyto autory musíme zařadit i D’Costu. V momentě, kdy se v teologickém diskursu o problematice křestanské reflexe ostatních náboženství setkáme s dovoláváním se k Trojici jako základní orientací teologie náboženství, je na místě se vážně ptát: Jaká trojiční nauka, lépe řečeno jaká trinitologie, je základem pro řešení problémů týkajících se náboženské plurality a vztahu křestanství k ní?

Teology náboženství, kteří se odvolávají na trojiční nauku, spojuje společná snaha o užívání trinitární gramatiky, jazyka z oblasti trinitologie, ale již zde rozhodně nelze předpokládat, že mezi nimi panuje shoda ohledně porozumění nauce o Nejsvětější Trojici. Na základě mapování diskuse v teologii náboženství tak lze vyslovit pochybnost, zda teologové, kteří pracují s trojiční naukou v souvislosti s náboženskou pluralitou a reflexí nekřestanských náboženství, tuto nauku spíše neohýbají způsobem, který se hodí do jejich vlastního konceptu náboženské plurality. Konkrétně jde o to, zda úmysl vysvětlit náboženskou pluralitu jistým způsobem nestojí na počátku teologického uvažování ještě před tím, než tito autoři přistoupí k nauce o Trojici s otázkou, zda nemůže právě tato nauka nabídnout vhodný klíč $\mathrm{k}$ interpretaci náboženské plurality.

Podle D’Costy nelze považovat trinitární učení za klíč k problému náboženské plurality. Trinitární orientace teologie náboženství v pojetí D’Costy spíše znamená, že křesṫanská trojiční víra je výchozím bodem a zároveň základním regulativem ortodoxní teologie náboženství. Trojiční nauka je spíše východisko, teologický předpoklad, než že by sloužila jako hermeneutický klíč, který by poskytoval vysvětlení faktu náboženské plurality. 
Samozřejmě, že jistá hermeneutická funkce trinitární doktríny se objevuje i u D'Costy. Jeho důraz na neredukovatelnou jinakost a partikularitu každé náboženské tradice, která vychází z neredukovatelné jinakosti trojjediného Boha, nám sdělené v partikulárním příběhu Ježíše z Nazareta, je toho do jisté míry důkazem.

V D'Costově trojičně orientované koncepci lze spatřovat naději, že teologie náboženství se vymaní z exklusivního zájmu o soteriologickou otázku, ačkoliv tématem tohoto traktátu zcela jistě zůstane i nadále. D’Costa však otevírá prostor k tomu, aby se hlavním tématem teologie náboženství stala otázka jinakosti a křestanského přístupu k ní. Manuály teologie náboženství by tak napříště neměly začínat dějinným přehledem vztahu křestanství k ostatním náboženstvím s ohledem na spásu nekřestanů, ale analýzou dějin křestanské interpretace náboženské jinakosti ostatních náboženství. Trojiční orientace D’Costovy teologie nás nabádá rovněž k tomu, abychom se zamysleli nad úlohou, jakou sehrává náboženská jinakost, respektive doktrína konkrétního náboženství ve svém vymezení vůči křestanství, i v ostatních systematicko-teologických pojednáních. Kolik manuálů pro trinitární teologii pracuje s námitkami muslimských a židovských teologů? Nakolik dogmatická teologie vnímá ostatní náboženství jako autentické loci theologici akademického bádání? Jsme připraveni nevzdat se své partikulární tradice a zároveň ji vystavit výzvám ostatních náboženství? Všechny tyto otázky, a našli bychom jistě další, je nutné klást si tváří v tvář dílu Gavina D’Costy, který je ve svých východiscích nezastřeně navázán na katolickou teologickou tradici, avšak ve vztahu k ostatním náboženstvím je otevřeným myslitelem, který dokáže připustit, že druzí jej mohou učit.

Na úplný závěr si dovolíme zmínit přesvědčení, které vyplynulo ze studia teologie zde představeného autora. Zaměření badatelské pozornosti na anglosaskou teologii by mohlo obohatit „domácí“ teologickou debatu v oblasti teologie náboženství a rozšířit povědomí o aktuálních otázkách této disciplíny. Pokud bude mít česká teologie odvahu otevř́t se jiným myšlenkám a účastnit se aktuálních debat, můžeme se těšit na zajímavé výsledky. V budoucnu by se třeba právě otázka trinitárního založení teologie náboženství mohla dočkat svého prohloubení od teologa, který pochází ze země Vladimíra Boublíka, jednoho ze zakladatelů teologického oboru, který se zabývá reflexí ostatních náboženství. 


\section{RESUMÉ}

MARTIN KOČÍ

Trinitarian Perspective of the Theology of Religions

An Outline of the Attitude to Non-Christian Religions in Gavin D'Costa

This study presents an analysis of the theological work of Gavin D'Costa. Author intends to introduce D'Costa's contribution in the field of the theology of religions and to examine the concept of Trinitarian Theology of Religions. D'Costa considers the doctrine of Trinity as the distinctive element of Christianity comparing to other religions. Paradoxically, he chooses the Trinitarian mystery as the point of departure in his approach to religions. He refuses incllusivist and exclusivist approaches. He believes that the socalled Trinitarian theology of religion can offer a respect-full evaluation of other religions. Simultaneously, such a concept remains faithful to the Christian tradition itself. This article highlights some debatable issues in D'Costa's concept. Author examines the dialectic between particularity and universality which is presented by D'Costa. In other words, this article deals with the question what has the priority: the particular event of Christ or the universal presence of the Holy Spirit in the world. D'Costa holds the balance between both 'events', even though he extensively elaborates upon the pneumatological-ecclesial perspective of the theology of religions. The consequences of this perspective are examined in the second half of this article. Finally, this article delves into the question about whether the Trinitarian doctrine can serve as a methodological principle of the theology of religions. And if the answer is positive, what concept of the Trinitarian theology is appropriate. Unfortunately, D'Costa does not provide any concrete answer in this respect. However, his intuition concerning the Trinitarian background of the Christian attitude toward other religions is an original contribution to the discipline of the theology of religions and enrichment for the current theological debate as such.

\section{Key Words}

Trinity, Theology of Religions, Gavin D'Costa, Religions 